\title{
ARANY JÁNOS ÚTJA A NAGY-KÖRÖSI KATEDRÁIG - TANULÓ ÉS TANÍTÓ ÉVEK 1817-1851 KÖZÖTT A FORRÁSOK TÜKRÉBEN
}

\section{Absztrakt}

Tanulmányomban elsődleges célul tűztem ki hazánk egyik legnagyobb költőjének, Arany János életének első felét úgy bemutatni, hogy írásomban rámutatok a költő életútjának főbb állomásaira, illetve azok egymásra gyakorolt hatására. Arany születésétől a híres nagykőrösi gimnáziumban töltött meghatározó kilenc évének kezdetéig, azaz 1817 és 1851 közötti időszakot bemutatva célom volt valamennyi tanulási és tanítási helyszínét ismertetni a poétának, melyek mind alkalmat biztosítottak Aranynak, hogy a tanulás adta tanítási lehetőségeit megismerhesse, képességeit és tudását fejlessze, valamint azokat eredményesen kamatoztathassa a különböző korcsoportok, módszerek és élethelyzetek során. Meggyőződésem, hogy ezen állomások Arany életében markánsan formálták a balladaköltészete mellett kibontakozó tanár képét mind önmagáról, a környezetéről, valamint a hagyatékáról. Kutatásomban a szakirodalom mellett a korabeli levelezések kritikai kiadását, valamint a vonatkozó verseket figyelembe véve próbáltam képet alkotni Aranyról, akiben egyszerre lehet tetten érni a tanuló és tanító vonásainak párhuzamát. Véleményem szerint Arany a sajátos életútjának is köszönhetően válhatott olyan kiváló tanítóvá, melynek példáját a XXI. században is szem előtt kell tartanunk. Elméleti jellegéből kifolyólag kutatásom rámutat a XIX. századi kultúra-, művelődés- és neveléstörténeti változásaira, valamint a korabeli elfogadott módszerekre, melyek közül némely irányzatot jelenünkben is használjuk, akár digitális formában is. Hiszem, hogy a magyar irodalom fejlődése gyökeresen összefonódott hazánk pedagógiai módszereinek fejlődésével, amelyek kéz a kézben együtt formálták a generációk sokaságát, így Arany szellemét is.

Kulcsszavak: Arany János; XIX. század; pedagógiai módszertan

\section{Bevezetés}

Arany Jánost, a magyarság valaha élt legnagyobb szókincsű emberének tartják, nem véletlenül, hiszen művein keresztül ismerhetjük meg igazán anyanyelvünk sokszínűségét és annak valós mélységét. A költő irodalmi korszakait tekintve láthatjuk, hogy a Toldi megírása, a balladaköltészetének kibontakozása, valamint az időskori, merengő Arany, mint életútjának mérföldkövei mellett a korszakok közötti átívelő, összekötő periódusokat is látnunk kell, mint például a forradalmár Arany égiszét, a katedrán számonkérő költőt és a megtört, kislányát elvesztő és egy időre elnémuló apát. Ezen időszakok markánsan változtatták meg Arany szellemét, valamint a külvilággal való kapcsolatát. Ezek a fordulatok befolyásolták nem csupán a nyelvezetét, a költészetét, hanem a munkája mellett a mindennapjait is. Ebből merítve a legérdekesebb és talán a 
legtermékenyebb időszak volt a nagykőrösi évek, amikor is 1851 és 1860 között Nagykőrösön a főgimnázium falai között oktatta a magyarság nyelvezetére és a nemzeti érzésre a diákokat, ezzel formálva számtalan generáció gondolkodásmódját, ön- és nemzetképét egyaránt.

Nagykőröst megelőzve, Arany kezdetben a szalontai iskolában, majd a híres Debreceni Református Kollégiumban tanult, így az egyszerű alföldi schola mellett a szigorú, a felvilágosodás eszméit magáénak valló padokban tanult és formálódott benne a tanítás mechanikája. Ezen ismereteit felhasználva, később retorikájának köszönhetően tanulmányait megszakítva Kisújszálláson, majd reményekkel telve Debrecenben folytatva azokat, amelyet önként befejezve Szalontán és Geszten helyezkedett el, még végül utolsó tanári állomása Nagykőrösre hívta.

Életútja során számos pedagógiai módszert ismert meg, hiszen a falusi környezetből csöppent a teológia irányította világba, ahonnan az Alföld nem engedte, így alsó osztályos diákokkal való munkára, továbbá magántanítói tapasztalatokra is szert tett. Tanulás és tanítás: 1851-re Arany megérett a magasabb katedra betöltésére, így a felvértezett ifjúról, aki ekkor még csak 34 éves, családját és nemzetét szerető és féltő, tettvágytól égő ember képe rajzolódik ki a kálvinista gimnázium falai között. Az irodalmár költő napjainak egyik felét az ifjúságnak, maradék idejét további munkáinak, így az írásnak szentelte. Ebben a történelem írta vészkorszakban Arany a maga teljességében bontakozott ki, így a Toldit követő balladái révén a koszorús nagyjaink közé emelkedhetett. Lássuk, hogy az iskola, a tanulás és tanítás hogyan formálta Arany életének első felét!

\section{„Szülöhelyem, Szalonta, / Nem szült engem szalonba...”}

\section{(Keresztury \& Keresztury, 1973, p. 360)}

1817. március 2-án látta meg a napvilágot Arany János. Kilenc testvére közül nyolcat a kor pusztító betegsége, a tüdőbaj (= gümőkór, = tuberkolózis) örökre elszakított az egyszerű földműves családtól, így a kis Jánost féltő gonddal óvták a szülei mindentől. Az atyai szemek természetesen nem csupán óvták, hanem figyelemmel is kísérték a gyermek fejlődését, amelyhez a szülői tanítás is párosult. 1768-ban, mikor János apja, György mindössze még tíz éves volt, komoly jogi procedúrába bonyolódott a család Bihar vármegye törvényszékével, ugyanis a Causa productionalist, azaz a nemességvitató pert megindították. Sajnos ez a per évtizedekig megoldatlan maradt, az édesapa idősebb fejjel sem hagyta ezt a családi sérelmet, végül így gondolkodtak János fiataléveiről ennek kapcsán: „A megtört szülők gyermekök ápolgatásában, nevelésében s a vallásosságban találtak vigasztalást. Édes apja meg különösen abban, hogy az eleven-eszű Janikát »fiskálisnak« taníttatja, a ki majd kiperli az Aranyok igaz jussát. Így Janikát erőjökön felől is taníttatni kivánták, apja a hamuba korán oktatgatta betüvetésre." (Gyöngyösy, 1901, p. 20). Erről maga a költő is beszámolt 1855. június 7-én kelt levelében Gyulai Pálnak: „,..alig 3-4 éves koromban apám, ki értelmes, irástudó paraszt ember volt - hamuba irt betűkön megtanita olvasni..." (Keresztury, 1982, p. 555).

A kíváncsi ifjú gyermekkorában számos meghatározó esemény volt, amely egyre jobban a tanulás és így a tanítás világába vonzotta, amelyre példa a Szalontán anyai 
nagyapjának házánál tartott mennyegző, ahol Juhász Mihály dinnyecsősz komédiázik egy tetszhalott felett tartott prédikációjával, amelynek a kis János nem értette a tréfa mellett a könyvből olvasottak tartalmát. Végül a kisfiú megkérdezte az öreg csősztől, mi a titka, hogy hogyan olvas ily sokat a könyvéből. Erre sem maradhatott el a válasz: „Hej fiam, ha én olvasni tanultam volna, nem lennék most dinnyecsősz és a város bolondja. Egy darab kenyér jutott volna öregségemre is." így "Janika most még büszkébb lett betütudományára, haladt is benne erősen.” (Gyöngyösy, 1901, p. 22). Ezt követően hatéves korában az ifjú János beszökött a templomi karzatra, ahol a kántor, Csere József egyből felfigyelt a gyermek képességeire, így azt Szabó Károly rektorhoz vitte, mintegy „csodagyerekként” bemutatva neki. A Schola Reformata soraiba történő beíratás sem váratott sokáig magára, amelyről a költő Nagykőrösön, 1855. június 7 -én Gyulai Pálnak írt levelében így számolt be: „... hova módnélkül vágytam, s a mi nem erős testalkatom s a szülék féltékenysége miatt csak 6-ik esztendős koromban történt..." (Keresztury, 1982, p. 555).

Arany tehetsége már kisiskolás korában kitűnt. Így fogalmazott kisdiák magáról: „...már nemcsak tökéletesen olvasni, de némi olvasottsággal is birtam, természetesen olly könyvekben, mellyek kezem ügyébe kerűltek..." (Keresztury, 1982, p. 555). Dévai Bálint fiatal preceptorra így emlékezik a költő: „A tanitó, megpróbálván, rögtön, a mint felvittek, elsőnek tett osztályában, s e helyet folyvást megtartottam.” (Keresztury, 1982, p. 555).

\section{1. sz. kép: Az egykori szalontai iskola, ahol Arany tanult és tanított}

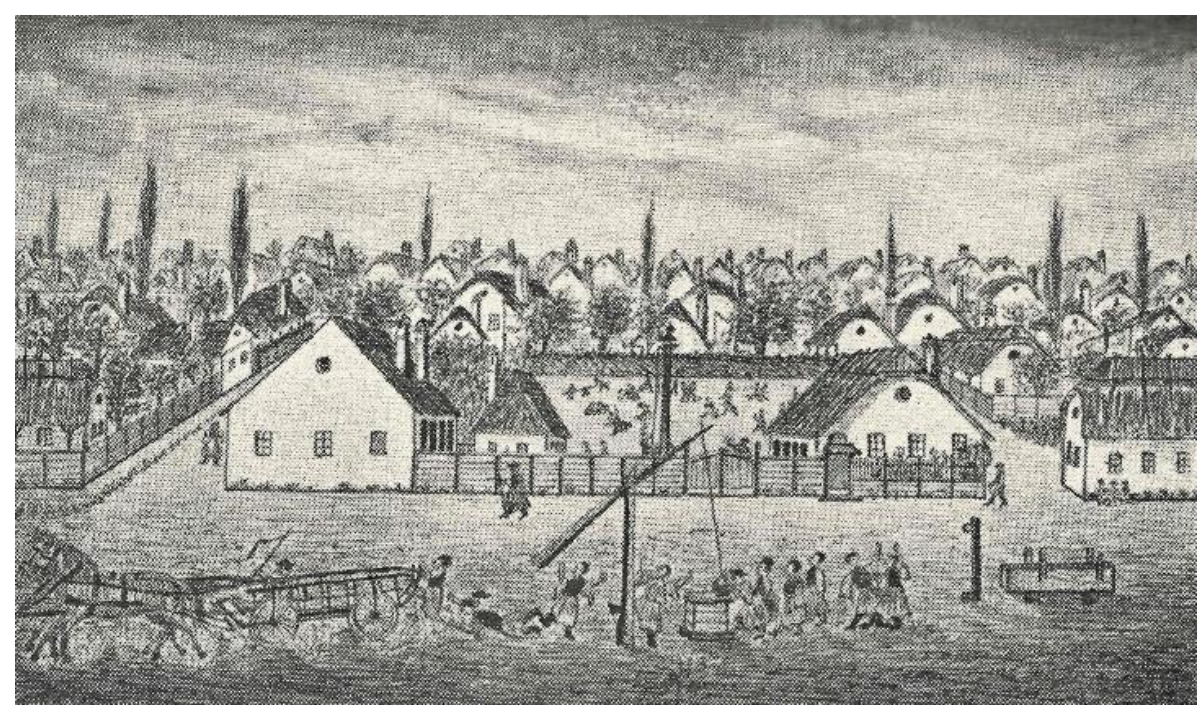

Forrás: Voinovich, 1929, pp. 48-49. közötti melléklet

A kor iskolai rendszerét jellemzően, így a szalontai iskolát is (mint az akkori gimnáziumokat pótló particulákat), a rektor vezette, amely mellett a fiú elemi iskolák V. és VI. osztályait a poeták és rhetorok is tanították. A rektor mellett legfeljebb egy corrector múködött, aki a tanítást segítette, továbbá aki az altanítókra felügyelt. A grammatisták a gimnázium első két, a syntaxisták a harmadik, illetve negyedik, míg a poeták az ötödik és végül a rhetorok a hatodik osztályból kerültek ki (Gyöngyösy, 1901; Dánielisz, 1992). Ebben az időszakban, az akkor oly híres századeleji Bell-Lancaster-féle módszert (monitorrrendszer) (Pukánszky, 1997) tevékenyen alkalmazták Szalontán is, így a 
legjobb tanuló legelől, míg az osztályban egyre hátrébb rendre gyengébb teljesítményű diákok ültek a padokban. Maga a módszer mind előnyöket, mind hátrányokat egyaránt tartalmazott. Előbbire jó példa volt a tanulók egymás közötti versengése, a tanító (mivel az alapötlet a XVIII. század végi angliai tanítóhiányokon alapult) segítése egy, a tanulók közül kijelölt „segédtanító” révén, amelynek vezérelve a kölcsönös oktatás volt, ugyanakkor hátrányai között szerepelt többek között a tanulók megkülönböztetése, az évfolyamok egyszerre oktatása, valamint a tanító és a diákság személyes távolsága, így az egyedi igények és módszerek alkalmazásának nélkülözése egy-egy tanuló esetében. Az új, globális pedagógiai módszer hazánkban a reformkorban erősödött meg igazán, míg a világ más részén viszonylag rövid ideig maradt alkalmazásban. A magyar oktatási rendszerben továbbélő módszer ékes példáját Karinthy Frigyes 1916-ban közreadott Tanár úr kérem című karcolatfüzérében, A jó tanuló felel című részben olvashatjuk: „A jó tanuló az első padban ül...” míg „Eglmayer, az utolsó padban egészen elbújik Deckmann háta mögé, ő nincs is itt, köszöni szépen, nem tud semmiről, őt írják be a hiányzók közé, töröljék ki az élők sorából, őt felejtsék el, béke poraira, ő nem akar részt venni a közélet küzdelmeiben.” (Karinthy, 1916, p. 43), majd A rossz tanuló felel című résznél így gondolkozik a felelő: „ő még felel. Most végigmenjen, újra, a padsorok közt?” (Karinthy, 1916, p. 44), így mutatva be Karinthy a XIX-XX. század fordulójának magyar iskola reális életképét. Ilyen szalontai milliőben cseperedett fel Arany és tanulta meg a tanítás alapjait egyfajta autodidakta módon, amelyben 20-30 társa nem csupán partner, hanem későbbi tanítói és tanári pályafutásában segítője is volt.

1826. november 1-ét írunk, amikor Arany belépett a „deák oskolába” (Dánielisz, 1992), ahol a gondolkodás eszköze immár a latin nyelv, amelyet később maga Arany is tanított, többek között Nagykőrösön. A Ratio Educationis Publicae 1806-ban megjelent rendelete alapján ugyanis a középiskolai oktatás nyelve továbbra is a latin maradt, de mellette igen nagy szerepet kapott a magyar nyelvű oktatás is (továbbá az egyéb nemzetiségi nyelvek, ahol az volt többségben) (Dánielisz, 1992). Fontos megjegyeznünk, hogy a latin tanulása nem szorítkozott az órai előadásokra, hanem a szünetekben játszó gyerekek nyelvezete is ez volt, ugyanis ha valamely diák önkéntelenül magyar szót ejtett ki, azt megbüntették, illetve megvetették (Dánielisz, 1992). Erre jó példa az alábbi történet: A diák Arany egyik társa, Pápai Ferencz társával egy alkalommal magyarul beszélgetve lépték át az iskola küszöbét. A szemfüles János azonnal rendre intette társait: „Non licet hungarice narrare.”, azaz „Nem szabad magyarul beszélni.” (Gyöngyösy, 1901, p. 32), amelyre Pápai egy fadarabbal (melyet fütésre hoztak az iskolába) Arany kabátját elszakította. Erre mérgében János latinra fordította az „Egyen meg a f...!” káromkodást amelyet Gyöngyösy (1901, p. 32) tévesen fordított, így az eredeti kifejezés, a „Cancer edat te!”, azaz a „Rák egyen meg!” a pontosabb. Nyelvi érdekesség, hogy a rákfene összeolvadt kifejezésünk innen eredeztethető. Végül a rector kérdőre vonta a diákokat a hangoskodásuk miatt, amelyre Arany így felelt, természetesen latinul: „Iste Franciscus Pápai laceravit meum meum izé!” (Gyöngyösy, 1901, p. 33), persze nem tudva a bunda latin megfelelőjét, így az „izé” kifejézést használta, amely a ma is elterjedt, nem csupán diákszlengben ismert kifejezés. A rektor nevetésben tört ki, s végül saját bundáját adta az ifjú Jánosnak. A történet másik ízes csattanója, hogy természetesen a rektor sem mondta meg a bunda kifejejezést latinul, 
valószínűleg nem is tudta! A kisdiák Arany kitűnően teljesítette a követelményeket, továbbá ebben a kissé elnyomott, részben büntetőelvű oktatási világban egyre jobban foglalkoztatta a grammatical szépsége.

Eltel két év, míg végül 1828. november 1-én, amikor a syntaxista tanulmányait megkezdte, novitiusként a latin mondattan világában a diák Arany legnagyobb gondja a tankönyvek beszerzése volt, ugyanis a német nyelvvel ezidőben ismerkedtek meg a tanulók. A veteránus, azaz a negyedik osztályos diákok ekkor már földrajzot is tanultak, amelyben Arany szintén jeleskedett és amelyet jól mutat, hogy nagykőrösi tanárévei alatt rendszeresen olvasta a főgymnasium könyvtárának 1571-es Strabonis Rerum Geographicarum Libri Septemdecim kötetét, természetesen latin, illetve görög nyelven. Az iskola korabeli könyvtárkölcsönzési naplója, benne Arany János aláírásával a helyi múzeum egyik kincse. 1831 áprilisában újabb fordulatot vett Arany diákélete, hiszen az 1828-1829-es téli tanítást ki kellett hagynia a szülői féltés miatt, így az évismétlés új tanítóval, illetve megfogyatkozott évfolyamtársakkal folytatódott (Dánielisz, 1992). Ennek előnye volt, hogy így a gyerekek személyesebb oktatásban részesülhettek, amely Arany későbbi nagykőrösi éveiben is megmutatkozott a dolgozatok javításában, illetve az abban található intelmekben. Az ösztönös, a tanítók által sarkallt és a helyzet adta lehetőségekből kifolyólag a mindössze 16 éves Arany, aki akkora már a tanítás mesterségével nem csupán megismerkedett, hanem azt gyakorolta is, 1833-ban, tíz év szalontai tanulás után a költészeti osztályt befejezvén Debrecenbe költözött, ahol a Series Studiosorum lapjain bevezették a nevét, őt magát pedig a coetusok egyikének falai közé fogadták. Így szedte össze Szalontán Arany a tarisznyájába a tudás morzsáit, ahol „,... minden könyv, a mi kezem ügyébe kerűlt, mohó vágygyal lőn felemésztve.” (Keresztury, 1982, p. 555). Lássuk, hogy Debrecen milyen mérföldkő volt Arany életében!

\section{„Debreceni sokadalom! / Nézz e képre, halld meg dalom...”}

\section{(Keresztury \& Keresztury, 1973, p. 433)}

Arany 1851. április 10-én, fél évvel Nagykőrösre költözését megelőzően, a Családi körben saját magát így örökíti meg: „Olvas a nagyobbik nem ügyelve másra: / E fiúból pap lesz, akárki meglássa! / Legalább így szokta mondani az apjok, / Noha a fiú nem imádságon kapkod: / Jobban kedveli a verseket, nótákat, / Effélét csinálni maga is próbálgat." (Keresztury \& Keresztury, 1973, p. 153). Arany itt a történeti hitelesség kedvéért testvéreit nem említi pontosan, ugyanis csak nővére, Sára élte túl a gyermekhalandóságot. Tanító, pap vagy nótárius lehetett azon ifjúból, aki Debrecent választotta. Arany tudásszomja a tanítás után a mindent megismerés felé terelődik, így például a kelet fényei felé tekint, olvassa a Koránt (Dercze, 1933), amely előre vetíti majd Vámbéry Árminnal való barátságát (Oláh, 2018). Erről így ír a híres orientalista dervisruhás utazó: „Arany nagykőrösi házánál aztán megfordultam többször én is. Szívesen látott, érdeklődött tanulmányaim iránt, szerette nyelvbéli tudásomat s egy ízben vendégül hivott asztalához is." (Vámbéry, 1905, pp. 92-93). Aranyt a coetus világában új impressziók érik, ugyanis ott a vegyes életkorú diákok között kell megtalálnia a számítását. Itt nyilvánvalóan barátságok szövődnek, amelyek majd emlékeztetnek minket 
a későbbi nagykőrösi barátságokra. Ezek a katedrán és a tanári szobában szövődtek, és élethosszig tartottak. Arany kíváncsisága kielégíthetetlen volt, ilyen téren „Idegennek érzi magát a 131 diák közt.” (Dercze, 1933, p. 5), ugyanis „Sokszor el-elgondolkodik. Elengedi képzeletét. Bejárja a légkört, megfutja a bolygók útját." (Dercze, 1933, p. 5). Végül a természet felé fordul, amit szeretett volna megismerni, de csupán a könyvek segítettek neki ebben. Diáktársainak csínytevései és a humoros légkör a nagykőrösi évek során is megjelent a Charivari és Contra Charivari élclapokban is, amely jelzi, hogy az apróbb ugratások nem csupán a diákság kiváltságai lehettek. Arany számos diáktársával kötött barátságot közös érdeklődési körük, puritán életük, valamint hasonló személyiségi jegyeik alapján. Kiemelendő Imre Sándor későbbi nyelvész, irodalomtörténész, akadémikussal való kapcsolata, amely a filozófia kurzus adta kollégiumban bontakozott ki. Barátságukat jellemezte, hogy Aranynak Imre „a vitákban már akkor pártját fogta, mikor még nem is nagyon tudta, hogy miről van szó.” (Imre, 2019, p. 118). Számtalan beszélgetésük, nyelvészdiskurzusuk sokszor a humor mögé bújtatott tanulói-tanítói kettős szerepben jelenik meg. Csokonai művei kettejük egyik közös pontja volt, amelyről így olvashatunk: „,... mikor szép időben a nagyerdőn kódorogtunk, hol az egyikünk, hol a másikunk mondott egy-egy töredéksort Csokonaiból, s a többinek ki kellett találni a folytatást. Arany, meg Imre Sándor mindig tudták folytatni s mindig tudták, mi miben van, melyik versében. Egyszer meg is tréfálta szegény Arany Imre Sándort. Már egy óra hosszánál is tovább verselgetünk így a nagyerdőn, mikor egyszer János mondott egy verssort s megkérdezte tőlünk, hát ez kitől való? - »Csokonaitól « - vágta rá tüstént Imre Sándor. »No, hát folytasd « - mosolygott Arany. »Folytatom is... mindjárt... rögtön eszembe jut.« S látszott rajta nagyon, hogy töri a csürhe járást. De bizony csak sehogy se akart eszébe jutni a vers párja. Arany nevetett, kacagott, Imre Sándor szorult. - »Tán nem is Csokonaitól van az, te« - évődött vele. De az erősködött, hogy igenis Csokonai, megesküszik rá, ha kell. Elég az hozzá, hogy majd félóráig kínozta, gyötörte vele Imre Sándort, míg végre megmondta, hogy az ő fejében született meg az a verssor, de ő se tudná folytatni, mert nem tudna rá kádenciát..." (Imre, 2019, p. 118). Ezen dialógus is rámutat Arany közvetlenségére, humoros oktatási módszereire és tréfás számonkérésére, amely a nagykőrösi katedrán is megelevenedik majd a későbbiekben.

2. sz. kép: A Debreceni Református Kollégium óépületének rekonstruált képe

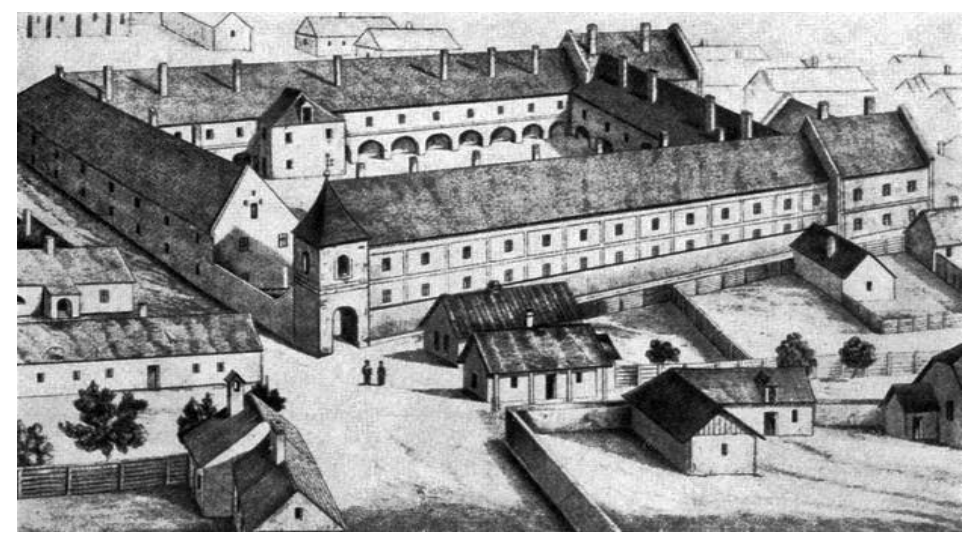

Forrás: Keresztury, 1974, p. 16. 
Fontos látnunk, hogy Arany szorgalma az iskolaévek alatt, részben környezetének köszönhetően alábbhagyott, így például a „Kőfajtudományból” vagy ahogy a szakirodalomban megtalálhatjuk még: „kövész-tudomány”-ból (Voinovich, 1929, p. 30), amelyet az 1833-1834-es tanév első felében Kerekes Ferencz oktatott - a tanára értékelésében ezt olvashatjuk a Classis Studiorumban Arany neve mellett: „Examen non subiit, quia præceptor discessit ante examen” (Pap, 1912, pp. 8-9), azaz „Az ásványtan vizsga nem történt meg, mert a tanuló a vizsga előtt távozott." A gyenge eredmények nem tükrözték Arany tudását, így a következő szemesztert ugyan kihagyta, de pedagógusi pályára lépve tovább gyakorolta a tanítás művészetét, amely későbbi eredményeit igencsak javította. A fordulat ellenére Aranyban nem szűnt meg a tudás iránti vágy, hiszen Keresztury (1937, p. 13) munkájában így olvashatjuk a debreceni évek összegzését: „Később is tanulékony maradt és makacs önművelő; az iskolás embereket kerülte s a debreceni kollégium vaskalapos szellemének légkörében rosszul érezte magát. Kitünő megfigyelő volt, látta a körülötte folyó élet visszásságait.” Emellett az örökös anyagi gondok csak előmozdították Arany debreceni távozását, amelyről így írt: „E helyzet iszonyú volt reám nézve. Hány kiússza így a kollégiumot! Nekem nem volt erélyem küzdeni. Kedvem a tanulástól elment, s márcziusban Kis-Ujszállásra mentem...” (Voinovich, 1929, p. 34). Hiába tapasztaljuk a költő kollégiumi pályája során azon kettősséget, amelyben csillapíthatatlan tudásszomja vetekszik a körülmények adta egyéniségének vívódásával. Ezen ellentmondást Arany a visszavonulással tudta feloldani, amely életében többször bekövetkezett. Mindez új erővel, új lendülettel inspirálta a későbbi tanulásra és tanításra. Nem szűnt meg véleménye Debrecent elhagyva sem a tanulásról, valamint annak szellemiségéről: „„... még a grammatikai osztályba alig érve, már nem tudtam nagyobb embert, mint a könyv-, főleg a versírót..." (Keresztury, 1937, p. 14).

\section{„... el vagyok bocsátva a kis-újszállási iskola præceptorának.”}

\section{(Gyöngyösy, 1901, p. 41)}

1834. február 9-én Kisújszállás már tervezte egy új tanító fogadását, amelyről a kollégiumot is értesítették Somogyi Lajos esperes útján. A 17 éves Arany maga tanította írni, olvasni, énekelni, számolni a diákokat Kisújszálláson, mindezt meglehetősen nagy osztálylétszámok mellett. Az osztálynévsor, amelyet maga Arany írt, több helyen is pontatlan, amelynek okfejtését Máté (2018) adja közre. Érdekességként meg kell említenünk, hogy ezen irat eredetijének keresése a mai napig tart, bár a remény egyre halványabb annak ellenére, hogy a kritikai kiadásokban, valamint több monográfiában is feldolgozták azt. Arany nem szűnt meg pallérozni elméjét, hiszen a kisújszállási tanítói feladatok felélesztették benne a tanulás iránti vágyat, amelynek táptalaja volt Török Pál rektor, későbbi pesti superintendens híres könyvtára, amelyet Arany előszeretettel látogatott. Arany így írt erről az időszakról Nagykőrösön 1855. június 7-én kelt Gyulai Pálhoz intézett levelében: „Megtörtem a német grammatikát, az uj iskola költőivel... a franczia nyelv elemeivel is megbarátkoztam... Olvastam éjjel-nappal, ha hivatalom 
engedte." (Keresztury, 1982, p. 557). Láthatjuk, hogy a tanítói munka mellett Arany újra virágkorát érte, a tanítás mellett lényének része volt a tanulási vágy is.

3. sz. kép: A kisújszállási Nagyiskola utcai homlokzata

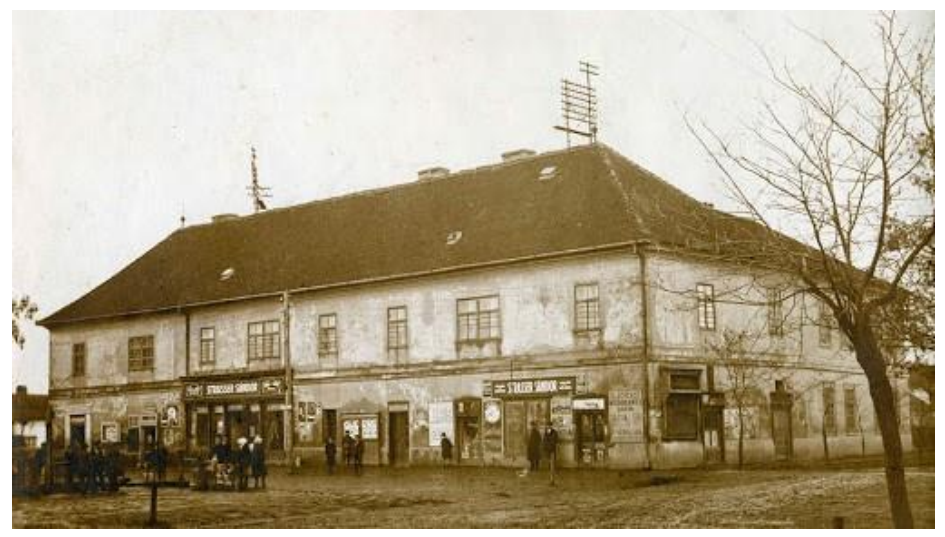

Forrás: Újszállási Rácz, 2018, p. 87.

Itt ismerkedik meg mélyebben Arany az újabb, Csokonai Vitéz Mihályt követő magyar nyelvvel és irodalommal, amelyre a debreceni falak nem adtak neki lehetőséget, ugyanis a kor romantikus irodalma a kollégiumban még ismeretlen volt ebben az időben. Ennek gyakorlati fontosságát majd a nagykőrösi éveknél láthatjuk, ahol Arany a katedrán a kortárs irodalmat is oktatta, így elveszett barátjának, Petőfinek a munkásságát is. A poéta tanítási módszereiről, sőt fegyelmezéséről Tóth Albert anyai dédnagyapjának Potsaji (Potsai) Ferentznek személyes élményei is információkkal szolgálnak, ugyanis a családi szájhagyomány így őrizte meg a kisdiák Arannyal kapcsolatos emlékeit: „,... nagyon szigorú ember volt, de rendkívül emberséges, a diákokkal is megértő. A rosszalkodó gyerekeket sarokba állította, akik súlyosan vétkeztek a fegyelem ellen, azokat tengeriszemre térdepeltette." (Máté, 2018, p. 24). Természetesen nem csupán diákszemmel kell látnunk Aranyt, hanem az iskola vezetőségének szemüvegén keresztül is, hiszen 1835. április 2-án „Kisújszállás Főbírája és Tanátsának Bizonyság levele” az alábbiakat adta közre Debrecen professzorainak Aranyról: „... a Tanítás[á]ra bízott apróbb gyermekeknek a Tudományokban, mind a jó erköltsökben való nevelés által magát ditséretesen megkülönböztette $s$ maga hellyes alkalmaztatása és erköltsi tulajdonságai, úgy Előljárói eránt mutatott engedelmes és jámbor maga viselete által magát mindnyájunk előtt megkedveltette, annyira, hogy mindeneknek, kik szolgálatjaival élni kivánnánk, ajánlani méltán bátorkodunk. ... a tanításban példás szorgalmatosságú és épületes, erköltsére nézve pedig jámbor és fedhetetlen Praeceptorunk volt." (Keresztury, 1975, p. 8; Máté, 2018, p. 30). Arany életének egy kevésbé ismert, magántanítói kitérője szintén ezen városhoz kötődik, hiszen Erdélyi József exegezis professzor őt bízta meg a hétéves kislánya, Lujza tanításával, cserébe a kevés kisújszállási fizetés mellé „ebédet adott neki.” (Dercze, 1933, p. 8). Dóczy így fogalmaz ezen megbízásról: „Ott is kosztolt egy darabig náluk. Szép kislány volt a Rózácska, de hej, sok baja volt vele Jánosnak." (Dóczy, 1929, p. 196). Érdekesség, hogy Dóczy Rózának említi Tánczos Kovács János ügyvéd későbbi feleségét. 
1936. április 2-án, napra pontosan 101 évvel később, amikor kiállították Arany „Bizonyság levelét”, született Kisújszálláson Csukás István híres írónk, a magyar gyermekirodalom egyik legnagyobb alakja, aki abban az iskolában tanulhatott, ahol a költő töltötte praeceptori idejét. Az író maga így vallott erről: „Az egyik csillag nekem ismerősebb lett, a földiek közvetlenségével biztatott. Vagyis nem könyvből kellett kiolvasnom, hanem benyithattam az ajtón a régi iskolába, ahol a lába nyomán léphettem, keze nyomát érinthettem, és láthattam volna kisdiák koromban az első költői »beszélye«, a »Rózsa és Ibolya « kéziratát. Ha el nem veszejtette volna a háború pusztítása. Az évek pusztítása sok mindent eltüntetett, házak dőltek, emberek haltak - de Arany János örökké él bennünk, erőt ad és életben tart." (Csukás, 2018, p. 132). Láthatjuk, hogy a költő és egyben tanító hagyatéka kisújszállási hivatalából távozva több mint száz év távlatában is befolyásolta sokak életútját, így bátran állíthatjuk, hogy Arany valóban örök.

\section{„... csak, csak classica litteratura...”}

\section{(Keresztury, 1937, p. 18)}

Arany a kisújszállási hivatalát feladva, újult erővel, a „Tiszavidék szellemi központjában” a „kálvinista Rómában” (Keresztury, 1937, p. 15) találta magát. Arany a 117 diák között a legjobbak közé tartozott, sőt tanárai is felfigyeltek a tehetségére. A költő idős fejjel, 1877. július 9-én jegyezte ezen sorokat, visszaemlékezve a pályaválasztásra Vásárban című versében: „Így - vézna, ügyetlen testi dolgokra - / Adtam fejem a bölcs tudományokra, / Barázda helyébe' szántva sorokat, / Nem kérkedem ezzel, mert azt se sokat." (Keresztury \& Keresztury, 1973, p. 377). Arany a környezetét látva újra megtört, a kezdeti debreceni fellángolás már csak pislákolt benne, hiszen „A jókedv közepette azonban Arany arca egyszerre komor lesz. Mintha eszébe jutott volna valami. Lelkéből vágyak buzognak fel. Más az a cél, amit maga elé kitűzött; amiért sóvárog." (Dercze, 1933, p. 10). Arany felindult állapotban volt ekkor, így hiába figyelt fel rá a Kisújszállásról származó Kerekes professzor, aki később a „Bont vegyítés tudományát”, a „Kémiai Atyafiságokat" (Voinovich, 1929, p. 39) oktatta a hallgatóságnak. Bár a kezdeti Mineralogia Examenre még emlékezhetett a neves professzor, érdeklődve figyelte Arany kollégiumi pályafutását.

4. sz. kép: Debreceni diákok Csokonai József, a költő édesapjának rajzolatában 1789 előtti viseletben

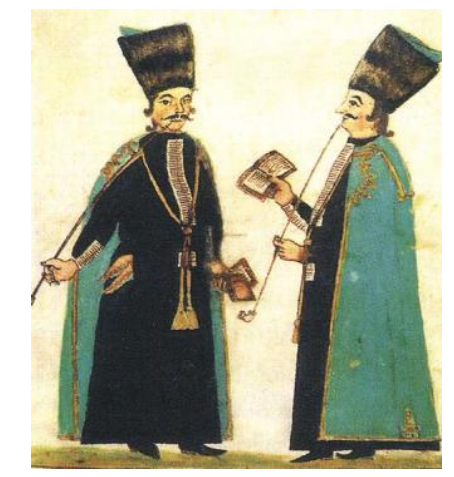

Forrás: Barta, 1997, p. 54. 
Arany Debrecenben megtapasztalhatta, hogy a városba inkább a híre, mint a hatása jutott el a kor romantikus költészetének, így Kölcsey vagy Kazinczy munkáit kevésbé ismerhette meg a kollégium katedráiról. Ennek voltak jótékony hatásai is, ugyanis a latin mellett egyre inkább a görög nyelv felé fordult, a drámaírók világa egyre jobban foglalkoztatta. Később Tasso, Schiller, Molière, Shakespeare következett, persze anyanyelvükön. Arany idegennyelvi pályafutásának igazi kezdőpontja Debrecenbe tehető, ahol bár elkeseredése és vívódása miatt fordult a nyelvek felé, később ezt kamatoztatni tudta további oktatói megbízásai révén. Sőt, elmélyült, könyvszerető ember lévén saját szórakozásból is olvasta a külföldi szerzők írásait, amelyeket később beépített a nagykőrösi gimnázium tananyagába, ezzel mutatva új irányvonalat a kálvinista oktatásban. Felkészültségét mi sem példázza jobban, mint „... nem volt még harmincéves, mikor már hat nyelven olvasott." (Keresztury, 1937, p. 17-18), tehát latinul, görögül, németül, angolul, franciául és olaszul, amelyek mellé anyanyelvét nem is számoltuk! Ebben a kettős életben döntést hozott végül. Csokonait olvasva és szem előtt tartva, a 19 éves Arany 1836 februárjában önkéntesen, érettségi nélkül hagyta ott Debrecent és vándorszínésznek állt, hiszen tanulmányai mellett a szobrászat és festészet „sem törte meg bánatát”. De Arany itt sem mellőzte a tanítást: „Óvatoskodott: kivette kollégiumi bizonyítványát s tovább adta magánóráit.” (Keresztury, 1937, p. 15). Sajnos ezen órákról az utókornak vajmi kevés információ áll rendelkezésre.

Sikertelenség, nélkülözés, reménytelenség jellemzi Arany ezen korszakát. Ezt tetézte a színésztársulatban megismert szubrettel, Klárics kisasszonnyal való viszonzatlan szerelmi kalandja, végül a kiábrándultság, aminek eredményeként hétnapi gyaloglás után szülei legnagyobb örömére hazatért Szalontára.

\section{„Azért vágyom naponta / Kunyhóba és vadonba."}

\section{(Keresztury \& Keresztury, 1973, p. 360)}

Édesanyja, fia hazatérését követően, pár héttel később elhunyt kolerában. Édesapja pedig megvakult (Gyöngyösy, 1901, p. 34), amiből orvosi közbeavatkozás nélkül pár év múlva felépült. Erről így olvashatunk: „vak apja - Isten csudája! - hirtelen visszanyeri szeme fényét" (Riedl, 1887, p. 8). Arany így a sok tanulás és tanítás után egyre melankólikusabb, helyzete egyre romlik. Szalonta előljárósága 1838 őszén megválasztotta correctornak, azaz tanítónak a rector után (Tóth, 1989). Gyulai Pálnak írt levelében, 1855. június 7-én így emlékezett Arany: „... az iskola épületébe költöztem én is. E hivatal, mellyben a magyar s latin grammaticai osztályokat tanítám, 1839-tavaszáig tartott... Ez idő alatt, 1836-40, nem szűntem meg folytatni olvasmányaimat, de inkább csak szórakozásból, mint ábrándos czéljaimat létesítendő, mellyekről, ha nem mondtam le végképp, nem volt reményem őket valaha elérni." (Keresztury, 1982, p. 559). Arany ezen megbízásában is folyton művelte magát, valamint jobb fizetése és több önállósága volt más tanítókhoz képest. Úgy tűnt, hogy élete révbe ért, hiszen rátalált a szerelem is, megismerte későbbi feleségét. Mivel a költő több időt szeretett volna párjával tölteni, 1839 januárjában lemondott tanítói állásáról és elfogadta a főszolgabíró írnoki felajánlását. Az ígéret nem vált valósággá, így Arany hivatal nélkül maradva kénytelen volt 
elvállalni Rozvány József kereskedő tízéves Erzsébet, sokszori megszólításban és a forrásokban „Betti vagy Betta” lányának tanítását. A költő ezzel nem csupán bevételre tett szert, hanem Rozványéknál is lakhatott.

5. sz. kép: Rozványi Erzsébet portréja

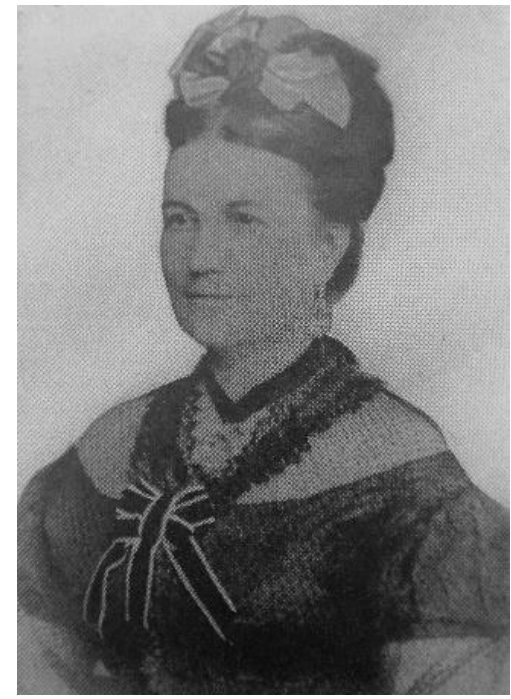

Forrás: Sáfrán, 1960, p. 32-33 közötti melléklet

Arany újra magántanító lett, így bensőséges, célzott feladatokkal oktathatta tanulóját és pedagógiai módszereit más környezetben is kipróbálhatta. 1847-ben Arany így emlékezik Egykori tanítványom emlékkönyvébe című versében Rozvány Erzsébetről: „Én láttam a bimbót, én láttam azt, / Midőn, érezve a nyájas tavaszt, / Kezdett kifejleni ... Érintsen bár hervadás szele, / Dús illatod, lényednek szebb fele, / A szellem élni fog!" (Keresztury \& Keresztury, 1973, p. 25). Természetesen diákja szintén versben fejezte ki érzelmeit tanítója iránt, akit rajongásig szeretett: „Mielőtt szellemeddel e hazát betöltenéd, / elbűvölé az már lelkét a gyermeknek, / ki áhítattal tekint föl reád: / szavaidra zsolozsmaként figyelt." (Sáfrán, 1960, p. 3). Arany fordításra is oktatta német nyelvből „Bettit”, de emellett a legfontosabb a magyar nyelvre való oktatás volt. Szóban és írásban így ösztönözte a költő tanítványát: „E szó honnan származik? Amit most mondtál, hogyan fejeznéd ki máskép? Hogyan volna helyes?” (Sáfrán, 1960, p. 34), vagy másik alakban „Hogyan helyesebben?” (Tóth, 1989, p. 21). Ezen érdeklődő, kérdésbe bújtatott ellenőrzőösztönző módszer később a nagykőrösi évek során is fellelhető, sőt, még írásban is megtalálható Arany híres házidolgozataiban. A német fordítási gyakorlatok fenmaradtak az utókorra, amelyekben láthatjuk, hogy Arany milyen humoros, de egyben tanulságos történetekkel készítette tanítványát a fordításra, akivel így a nyelvet is megszerettette. Lássunk néhány példát Arany tréfás oldalát megerősítendő: „5 Gyakorlás. Mikor a’ medvék tánczolnak, a' majmok rajtok ülnek és külömb külömféle bolondságokat csinálnak.” (Sáfrán, 1960, p. 129), „12k Gyakorlás. ... A szekér az udvarba taszitódik. ... Ki által huzódtak ki a' te rizs fogaid? Az egerek meg fogódnak a macska által." (Sáfrán, 1960, p. 130), vagy a „14k Gyakorlás. ... A’ barom vidámsággal telve ugrál / És szíjja a’ friss levegőt.” (Sáfrán, 1960, p. 132). Rozvány Erzsébet visszaemlékezésében felelevenítette Arany egyik meséjének végét, amellyel oktatta kislány korában: „Bizzunk Istenben 
gyermekem, mert benne meg nem csalatkozunk!” (Kolosvári, 1907, p. 23). 1898. február 8-án Kolosvári Aladárnak kelt levelében „Betti”, mint az akkor már férjezett Bersekné Erzsébet így emlékszik vissza híres költő-tanítójára: „Ő engemet inkább beszélve tanitott, meséit németül mondta el, melyet nekem aztán magyarul kelle elmondanom. És most ugy vélem, hogy ő ezzel magát is gyakorolta, mivel ő folyton tanult. A tanrendszer, vagy tantervről csak annyit mondhatok, hogy az csekély volt, de milyen tanrendszerünk is volt nekünk nőknek 59-60 évvel ezelőtt; akkori időben az is mirakulum volt." (Kolosvári, 1907, p. 24). Arany tisztában volt vele, hogy ezúttal leány magántanulója van, így oktatása inkább a mesélő, szívet és erkölcsöt erősítő szellemben folyt. Aranyné így emlékszik vissza egyik levelében a Rozgonyi család úrnőjére, aki támogatta a fiatal pár szerelmét: „,... felejthetetlen előttem, ki életemben, idegen létemre, legtöbb jót tett velem - mint fiatal, árva leánynak, kinek senkije sem volt, pártfogóm és oltalmazóm a mások bántalmai ellen." (Tóth, 1989, p. 22). Végül 1840. november 19-én Arany János és Ercsey Julianna örökre összekötötte életét, amelyre a költő 1869. július 12-én kelt Nőmhöz című versében így emlékezett: „Ifju voltál, ifju voltam, / Árva voltál, én szegény: / Nem volt messze olyan össze- / Illő pár a föld-tekén." (Keresztury \& Keresztury, 1973, p. 368).

\section{"Más ég hintette rám mosolyját..."}

\section{(Keresztury \& Keresztury, 1973, p. 103)}

Arany magántanítói megbízását követően 1840-től Szalonta másodjegyzője lett, 1841ben született kislánya, Juliska, 1844-ben Laci fia. Keresete és egzisztenciája nőtt, boldog családos férfi lett. Ennek ellenére újabb fordulat következett a poéta életében, amiről 1855-ben így írt Gyulai Pálnak: „Mindez házasságomig tartott, akkor föltettem magamban, nem olvasni többet, hanem élni hivatalomnak, családomnak, lenni közönséges ember, mint más. Pár évig meg is állám fogadásomat. ... ismét beléestem az olvasás ragályába, a nélkül, hogy komoly szándékom lett volna valaha mint író, <komolyan> föllépni. De nehéz volt ellentállnom a kisértésnek.” (Keresztury, 1982, p. 560-561). Az „irodalom fényes üstököse” visszatért, Shakespeare kiváló fordítója, Az elveszett alkotmány szatirikus eposzának szerzője, a Toldi megálmodója új korszakához ért. Utóbbi művéről Petőfi így írt Aranynak első, 1847. február 4-én kelt levelében: „Ha a nép uralkodni fog a költészetben, közel áll ahhoz, hogy a politikában is uralkodjék..." (Alföldy, 1995, p. 17). Arany 1847. október 11-én kelt levelében meg is osztotta Petőfi ezen gondolatait Szász Károllyal (Sáfrán, 1982, p. 76), akivel mélyebb barátságba Nagykőrösön került. Arany nagy változásokon ment keresztül gyermekeinek megszületése, azok nevelése, valamint a 48-as eszmék révén, melyek hatással voltak a család, a katedra és a balladák világában, Nagykőrösön töltött következő éveire. 
6. sz. kép: Petőfi 1847-ben készített rajza Arany Jánosról

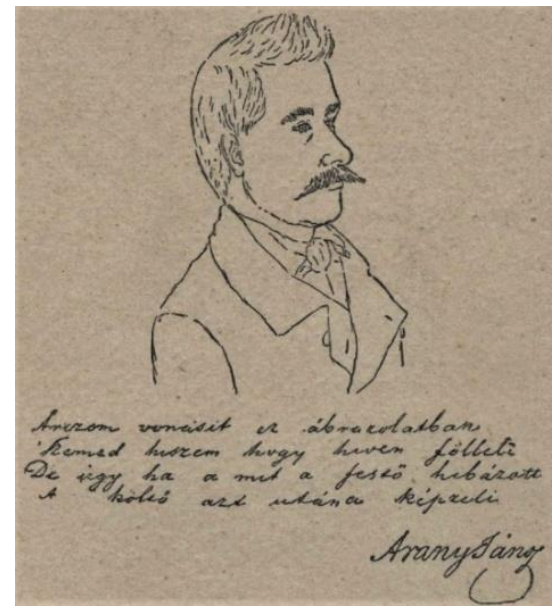

Forrás: Kozma, 1982, p. 96-97 közötti 10. melléklet

A költözést megelőzte az 1848-1849-es forradalom és szabadságharc, amelyben Arany aktívan részt vállalt mint nemzetőr, mint Petőfi barátja és támogatója, mint a Szemerekormány fogalmazója, mint Vas Gereben újságjának, a Nép barátjának szerkesztőtársa és mint a márciusi eszmék hirdetője. A szabadságharc bukásával Arany bujdosni kényszerült, a világosi fegyverletétel után közéleti szerepet nem vállalhatott. Visszatért Szalontára, ahol Szilágyi István 1850. január 4-én kelt levelében így érdeklődik: „Ne ütközzél tehát meg e csak néhány sorban, de szólj, írj, bár csak ennyit, s én nyugodt leszek." (Tóth, 1989, p. 97). A levélre Arany 1850. január 19-én szűkszavúan válaszolt, érződik a szabadságharc bukása utáni elégikus, olykor irónikus, sőt lamentáló kedve is: „Leveledet vettem s jólesett tapasztalnom, hogy még van ember, ki rólam emlékezik. Azonban tőlem körülményes választ ne várj, mert a körülmények nem engedik. Annyit írhatok, hogy egészség és levegő dolgában nem szűkölködünk. Itt, bérszobában lakunk etc., s élünk, ahogy lehet, míg lehet." (Tóth, 1989, p. 97). Ebben az elkeseredett helyzetben kínált neki magántanítói állást a kor egyik híres politikusa, Tisza Lajos a Szalontával határos Gesztről, akinek Arany nem mondhatott nemet. Tiszának személyes ajánlója az a Kovács János tanító volt, akiben Arany egykori kollégiumi társát tisztelhetjük és aki 1846 óta oktatta Tisza Domokost magyar, német, angol és francia költészetre. Emellett Aranynak régi ismerőse volt a geszti esperes, Szabó József is, aki gimnazista évei alatt 1829-ig az első rektora volt. Így Arany, közel a családjához, újra érezhette magában a tanítás adta tanulási vágyat.

\section{„... többnyire Geszten tanyázva...”}

\section{(Keresztury, 1982, p. 563)}

Arany a Bach-korszak kérlelhetetlen bürokráciájának megfelelően 1851. november 9én Nagykőrősön kelt levelében így fogalmazott a Császári és Királyi Tanhatóságnak megküldött önéletrajzában a geszti megbízásáról: „,... 1851 május 1-ső napjától fogva, mi igen sokak előtt tudva van, október közepéig, midőn e tanári székre meghivást kaptam, csász. kir. kamarás Méltóságos Tisza Lajos úr házánál Geszten mint a költészet és görög 
nyelv magán oktatója müködtem, ki, ha az idő rövidsége s távolság engedné, politikai s erkölcsi fedhetetlen magaviseletemről bizonyságot tenni hogy nem vonakodnék, legkevésbé sem kételkedem.” (Keresztury, 1966, p. 103). Érdekességként meg kell említenünk, hogy Arany később, 1853. június 7-i keltezéssel „Életrajzi pótlásban” erősíti meg geszti tartózkodását: „,... életem és törvényes viseletem a mélt. csász. kir. kamarás Borosjenői Tisza Lajos úr házánál töltött félévi időről is igazoltatik." (Keresztury, 1966, p. 104). A hatalmas főúri birtokon Arany együtt élt a Tisza családdal, így közvetlen kapcsolatban állt annak minden tagjával, sőt, ismerte a gyerekek játszópajtásait, valamint a rá bízott növendék minden tulajdonságát, a tanulásban erősségeit és gyengeségeit egyaránt.

7. sz. kép: Tisza Domokos portréja Barabás Miklós után

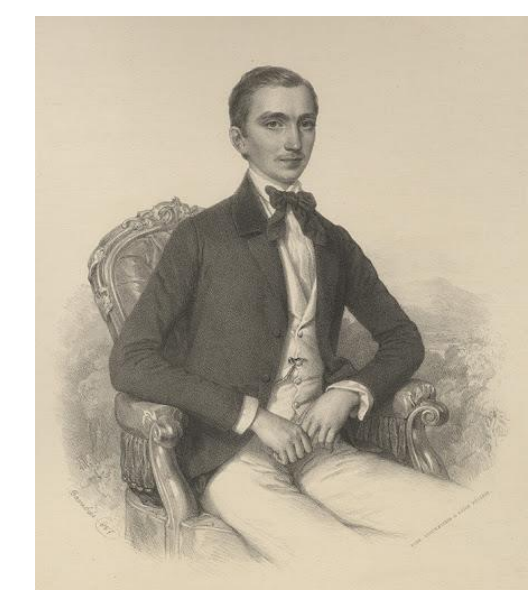

Forrás: Magyar Nemzeti Múzeum, Történelmi Képcsarnok, Grafikai Gyüjtemény, leltári szám: 4293.

Tisza Domokos oktatására napi két órát szabtak Aranynak, ez nem volt terhes, sőt, a klasszikusok olvasása és azok értelmezése Aranyban újra feltüzelte a tanítás fokozta tanulási vágyat. Ilyen érzése korábbi magántanítványainál is volt, akik szívesen visszaemlékeztek Arany ezen tulajdonságára. A szakirodalmak összevetésekor különböző kép formálódik meg azzal kapcsolatosan, hogy Arany mennyire volt motivált financiális téren: „... az ezért ajánlott honorárium elég kevés volt...” (Ercsey, 1883, p. 57), míg máshol ezt találjuk: „... abban az időben ez nem kevés...” (Voinovich, 1931, p. 63), de annyi bizonyos, hogy Arany szorult helyzetében és a kihívás okozta helyzetben azonnal elfogadta a magántanítói állást. Könnyen tanuló diákjával Arany hamarosan élethosszig tartó barátságot kötött, amelyről tanúskodnak Domokossal folytatott későbbi levelezései is. Arany 1851. november 2-i keltezéssel kapta az első levelet diákjától, melyet az utolsó levélig (amely 1855. augusztus 11-én kelt) pontosan 70 levél követett tanulójának tollából. Arany ezekre erejéből telhetően később is válaszolt. A levelekből 38 darab maradt fenn az utókorra. Domokos Arany bácsinak vagy Aranybácsinak szólította egykori mentorát írásaiban. Első levélváltásukban a diák így írt egykori tanítójának: „Nagyon óhajtom hallani, holy helyre vergődésük, mely anyi bajjal és boszúsággal szokott járni, végbe ment.” (Keresztury, 1975, p. 403). Domokos beszámolt Aranynak, hogy Geszten hagyta szobájában „Byron második kötetének néhány stanzás borítékát”, amely mutatja, hogy Arany az angol nyelvet mily behatóan ismerte. A diák hamarosan bálványozta 
tanítóját, akinek pedagógiai módszereiről így vélekedett Kovács János 1851. február 13án Aranynak kelt levelében: „... célunkat tökéletesen felfogta, s inkább képezni, mint tanitani akarja a kis költőt. Tehát üdvözlöm önt, mint nem csak foglalkozási de egyszersmind elvi tekintetben is tanitó társamat.” (Keresztury, 1975, p. 341). Később pedig Arany iránymutatásairól oly jellemző képet festett a költőnek szánt 1851. december 17-én kelt levelében: „Szellemed azonban el sem ment, s még mindig jóltevőleg hat Domokosra, annyival inkább, mert birálataid által izlést és irányt adni egy leveledben sem múlasztod el." (Keresztury, 1975, p. 429). Arany motiváltságát más szakirodalomban is a legnagyobb magasztossággal jegyzik, amelyről Voinovich (1931, p. 68) így számol be: „... tudta egyes helyekből az általános igazságokat, hibákból a helyes szabályokat kiolvasni s úgy hajolni le tanítványa értelméhez, hogy őt feljebb emelje. Arany érdekelni, lelkesíteni is tudta tanítványát, s »a tanítás óráin maga is fellelkesült«.” Arany Domokoshoz való hozzáállását személyesen is kifejtette Domokos napra című, 1851. augusztus 4-én papírra vetett versében, ahol így inti tanulóját a jövőre nézve: „Legnagyobb cél pedig, itt, e földi létben, / Ember lenni mindég, minden körülményben. / Serdülj, kedves ifju... poharam cseng érted! - / Légy ember, ha majdan azt az időt éred." (Keresztury \& Keresztury, 1973, p. 166). Ezen sorokra később, János napra, így ír Domokos Aranynak címzett 1853. január 6-án kelt levelében. „... nem tudok oly nem köszöntő köszöntő verset írni, mint a milyet én egyszer kaptam, s ez, úgy vélem, nem is csuda..." (Keresztury, 1982, p. 142). A rövid, mintegy fél éves magántanítói megbízást a nagykőrösi meghívás követte. Amikor Arany elhagyta Gesztet, azzal együtt Szalontát is elhagyta, ahová sosem tért vissza a költő, csupán gondolataiban. Tisza Domokos végül mindössze 18 évesen, 1856. június 21-én elhunyt.

\section{Összegzés}

Arany János életútja mondhatni nem szokványos, hiszen számos nehéz helyzetben kellett életre szóló döntéseket hoznia. Az általa bejárt út, a nagykőrösi költözésig megtapasztalt számtalan élethelyzet, illetve megismert oktatási módszer, valamint a különböző korcsoportok és a sajátos nevelési igényekhez való alkalmazkodása révén válhatott igazán kiváló tanárrá. Az alsóbb osztályoktól, a kisebb és a nagyobb létszámú közösségekig, valamint magántanulói révén rendre olyan módszerek alakultak ki pedagógusi munkájában, amelyeket később, a kőrösi gimnázium falai között hatékonyan alkamazhatott. A generációk nevelése során Arany nem csupán passzív szerepre vállalkozott, hanem aktívan vállalta nézeteit, véleményét, valamint jobbító gondolatait iróniával és humorral közvetítette. Nem véletlen, hogy minden magántanítványa hálával emlékezik meg Aranyról versben vagy levélben, amely jól mutatja a költő közvetlen, barátságos, tanításra alkalmas természetét.

1851. augusztus 4-én kelt Domokos napra című művében így inti fegyelmere egykori diákját: „Előtted a küzdés, előtted a pálya, / Az erőtlen csügged, az erős megállja. / És tudod: az erő micsoda? - Akarat, / Mely előbb vagy utóbb, de borostyánt arat." (Keresztury \& Keresztury, 1973, p. 166). A költő pályája során folyamatosan pozitív megerősítésben formálta a tanulók szellemét, amelyet maga is keresett egykoron 
diákként. Az önként vállalt segédtanítói megbízás, a diáktársakkal folytatott eszmecserék, a házifeladatok nem csupán a rá bízott gyerekeket, hanem magának a költőnek az egyéniségét is erősítették. Az alkotáshoz Aranynak erre mindenképpen szüksége volt, hiszen neveltetése és puritán környezete okán külső megerősítést igényelt. Tanulás és tanítás így forrt egybe Arany lelkében, amelynek objektív leképezése részben levelezésében, részben alkotásaiban világlik ki igazán. Szalonta, Debrecen, Kisújszállás, újra Debrecen, megint Szalonta és végül Geszt predesztinálta Aranyt, hogy 1851 őszén Nagykőrös város büszkeségeként vonuljon be nem csupán a magyar irodalomtörténetbe, hanem lényéből fakadóan a kultúra-, a művelődés- és a neveléstörténet nagyjai közé is. Nem véletlenül írt Petőfi 1847 februárjában Arany Jánoshoz című versében így a költőtársához: „Ki volt tanítód? hol jártál iskolába? / Hogy lantod ily mesterkezekkel pengeted. / Az iskolákban nem tanulni, hiába, / Ilyet... a természet tanított tégedet." (Kiss, 1981, p. 19). Ezt az Arany Jánost is ismernünk kell, hiszen szelleme és hagyatéka velünk volt, van és lesz mindörökre.

Arany XXI. századi továbbélését mi sem bizonyítja jobban, mint a születésének bicentenáriuma alkalmából és az azt követően megjelent tudományos és ismeretterjesztő írások sokasága, melyből a teljesség igénye nélkül ki kell emelnünk a 2017-ben megjelent kötetek közül Reisinger János Ki nekünk Arany János?, Szilágyi Márton „Mi vagyok én?” Arany János költészete és Szörényi László Arany János évében - Tárcák és tanulmányok című műveket, a Korompay H. János szerkesztésében közreadott „Óhajtom a classicus írók tanulmányát” - Arany János és az európai irodalom című tanulmánykötetet, valamint a Hitel című folyóiratban Nyilasy Balázs Arany János és a magyar irodalomértés az új évezredből visszanézve című írását. 2018-ban szintén számos kíváló írás jelent meg Aranyról, így megemlítendő a Vaderna Gábor főszerkesztésében megjelent Önarckép álarcokban - A Petőfi Irodalmi Múzeum Arany János-kiállításának katalógusa, a Török Zsuzsanna és Zeke Zsuzsanna tollából megjelent Az Arany család tárgyai, valamint a Kaszap-Asztalos Emese és Sidó Anna szerkesztette „Melyik talál?” - Arany János életében készült képmásai című művek. 2019-ben Korompay H. János „Bénult idegre zsongító hatás” - Arany elemzések, a Cieger András szerkesztette „Hazám tudósi, könyvet nagy nevének!” - Arany János pályájának művelődéstörténeti olvasatai című kötetek, valamint Szilágyi Mártonnak az Irodalomismeret folyóirat 4. számában megjelent Szilágyi István és Arany János barátsága az 1840-es években - Egy alkalmi Arany-vers tanulságai című írása emelkedik ki. 2020-ban Szilágyi Márton Omniárium című műve mellett szintén megemlítendő Az Alföld folyóirat 2. számában S. Varga Pál, Vaderna Gábor és G. István László írásai is. Mindezekből egyértelműen látható, hogy Arany és gazdag kultúrateremtő, közvetítő és ápoló hagyatékának fénye örök nemzetünk nyelvében és történetében.

\section{Irodalomjegyzék}

Alföldy, J. (1995). Arany és Petőfi levelezése prózában, versben. Budapest: Mágus.

Barta, J. (1997). A kétfejü sas hatalmában. Budapest: Magyar Könyvklub - Helikon Kiadó.

Csukás, I. (2018). Arany János közönséges tanítása. In Ducza, L. (szerk.), Arany-emlékeink. Helytörténeti füzetek 40. (pp. 132-133). Kisújszállás: Kisújszállás Város Önkormányzata.

Dánielisz, E. (1992). Arany János a szalontai iskolában. Budapest: Országos Pedagógiai Könyvtár és Múzeum. 
Dercze, L. (1933). Arany János és Debrecen. Debrecen: Bertók Lajos.

Dóczy, J. (1929). Arany János életképek. Budapest: Genius.

Ercsey, S. (1883). Arany János életéből. Budapest: Ráth Mór.

Gyöngyösy, L. (1901). Arany János élete és munkái. Budapest: Franklin-Társulat, Magyar Irodalmi Intézet és Könyvnyomda.

Imre, L. (2019). Debreceni iskolatársak: Arany János és Imre Sándor. In „Az életet, ím, megjártam”. Tiszántúli Református Egyházkerületi Gyűjtemények Kiadványai (pp. 113-124). Debrecen - Budapest: Debreceni Református Kollégium Múzeuma - MTA BTK Irodalomtudományi Intézet - MTA Könyvtár és Információs Központ.

Karinthy, F. (1916). Tanár úr kérem. Budapest: Dick Manó.

Keresztury, D. \& Keresztury, M. (1973). Arany János összes költeményei I. Budapest: Szépirodalmi Könyvkiadó.

Keresztury, D. (1937). Arany János. Budapest: Magyar Szemle Társaság.

Keresztury, D. (1974). Így élt Arany János. Budapest: Móra Könyvkiadó.

Keresztury, D. (szerk.) (1966). Arany János összes múvei XIII. Hivatali iratok I. Nagyszalonta - Nagykörös Budapest (1831-1865). Budapest: Akadémiai Kiadó.

Keresztury, D. (szerk.) (1975). Arany János összes müvei XV. Levelezés I. (1828-1851). Budapest: Akadémiai Kiadó.

Keresztury, D. (szerk.) (1982). Arany János összes müvei XVI. Levelezés II. (1852-1856). Budapest: Akadémiai Kiadó.

Kiss, J. (1981). Petőfi Sándor összes költeményei II. Budapest: Szépirodalmi Könyvkiadó.

Kolosvári, A. (1907). Arany János élete. Mezőtúr: Török Ignác.

Kozma, D. (1982). Arany János brevárium. Kolozsvár: Dacia Könyvkiadó.

Máté, I. (2018). A múlt és Arany. In Ducza, L. (szerk.), Arany-emlékeink. Helytörténeti füzetek 40. (pp. 17-33). Kisújszállás: Kisújszállás Város Önkormányzata.

Oláh, R. (2018). Nagykőrös és a Kelet kutatásának kapcsolata. In Szigeti, M. (szerk.), Nagykőrösi Kalendárium 2019 (pp. 117-121). Nagykőrös: Fraxinus Egyesület.

Pap, K. (1912). Adalékok Arany debreczeni diákságához. Budapest: Franklin Társulat.

Pukánszky, B. (1997). Pedagógiai lexikon II. Budapest: Keraban Könyvkiadó.

Riedl, F. (1887). Arany János. Budapest: Hornyánszky Viktor.

Sáfrán, Gy. (1960). Arany János és Rozvány Erzsébet. In Keresztury, D. \& Somogyi, S. (szerk.), A Magyar Tudományos Akadémia Könyvtárának Kiadványai 19. (pp. 1-178). Budapest: Magyar Tudományos Akadémia.

Sáfrán, Gy. (1982). Arany János leveleskönyve. Budapest: Gondolat.

Tóth, T. (1989). Aranytól Aranyról. Budapest: Tankönyvkiadó.

Újszállási Rácz, L. (2018):: Hol lakott? Hol dolgozott? Merre járt-kelt?. In Ducza, L. (szerk.), Arany-emlékeink. Helytörténeti füzetek 40. (pp. 83-104). Kisújszállás: Kisújszállás Város Önkormányzata.

Vámbéry, Á. (1905). Küzdelmeim. Budapest: Franklin-Társulat, Magyar Irodalmi Intézet és Könyvnyomda. Voinovich, G. (1929). Arany János életrajza 1817-1849. Budapest: Magyar Tudományos Akadémia. Voinovich, G. (1931). Arany János életrajza 1849-1860. Budapest: Magyar Tudományos Akadémia. 